\title{
Nuclear weapons and alliance institutions in the era of President Trump
}

Stephan Frühling, Strategic and Defence Studies Centre, Australian National University, Australia

Andrew O’Neil, Griffith Business School, Griffith University, Australia

The election of Donald Trump as the next U.S. president seems to herald a time of volatility, if not crisis, in U.S. alliances worldwide. During the election campaign, Trump characterized America's NATO allies, Japan, and South Korea as free riders, and embraced a more transactional approach to international relationships than has been the case with US presidential candidates in the recent past (Sanger and Haberman. 2016). Trump's solution to the alleged free riding of Japan and South Korea promised a radical change in U.S. alliance and non-proliferation policy: If elected President, he would give the green light for Tokyo and Seoul to develop their own nuclear forces rather than them relying on the U.S. nuclear umbrella (Lee and Sonne, 2016).

The advent of the Trump administration has thus given unexpected currency to the relationship between alliance institutions and U.S. nuclear weapons policy that we discuss in our article, "Nuclear weapons, the United States and alliances in Europe and Asia: Toward an Institutional perspective" (Frühling and O'Neil, 2017). Rather than seeing nuclear weapons cooperation as a binary extended deterrence relationship where the United States supplies, and allies passively receive, security, we argue that cooperation on nuclear posture, strategy, and policy should be seen as an institutional means that reinforces alliance cohesion, including at times when this cohesion comes under threat from perceptions of differing strategic priorities among allies.

We are very grateful to Jeffrey Knopf, Van Jackson, and Alexander Lanoszka for taking the time to engage with and respond to our article. Each author has made significant contributions in their own right to scholarship on nuclear policy and extended deterrence (see Knopf, 2012; Jackson, 2016; Lanoszka, 2016), and given that one of the main aims of our article was to trigger further analysis of the relationship between intra-alliance dynamics and nuclear weapons, we are pleased to have the opportunity to respond. All three constructively identify areas of weakness in the article and propose areas for further exploration in future research.

Jackson's (2017) article is a thoughtful reflection on our arguments, which focuses on several questions about bargaining, credibility, and deterrence "that become even more salient in tandem with a Trump presidency." Jackson observes that we "may be overstating the extent to which non-nuclear clients are capable of shaping US nuclear policy. At a minimum, Trump will provide a hard test of their claim." This a point well taken and Jackson is almost certainly correct in his diagnosis that Trump believes there is no alliance deterrence, only deterrence extended by a benevolent United States. 


\section{How robust are alliance institutions?}

Lanoszka (2017) rightly notes that worries about nuclear disarmament gaining traction have faded rapidly and attention is now turning to a different concern: That the United States under a Trump administration will be more inclined to engage in nuclear sabre-rattling and regard nuclear proliferation among close allies as a positive rather than negative development. For Lanoszka, "To the extent that alliances feature institutional constraints, it appears they might be too delicate to survive his presidency."

Jeffery Knopf (2017) is also concerned that Trump may damage the institutional fabric of U.S. alliances. That may turn out to be so, but institutions also give allies the opportunity to question and explore U.S. motivations, to signal and make concessions (in a sense, for example, the existence of NATO's agreed 2\% of GDP goal for defence expenditure is also an outcome of institutionalization). They will give Trump opportunities to walk back from his own rhetoric, and create the need for actual decisions that will, for better or for worse, force him to confront the consequences of his ideas, well before a potential failure of U.S. extended deterrence.

Influential voices in the United States are already calling for the Trump administration to accelerate the modernization of U.S. nuclear arsenal (Miller and Payne, 2016) and Trump has once again signalled his strong intent to do so (Wayne, 2016). If this does occur, what would Trump's position be on the modernization of the European-based B-61 nuclear warheads assigned to NATO? He may seek to use them as leverage for European concessions, but whatever deal the allies strike in the following negotiations, it would likely perpetuate, and perhaps even reinvigorate, NATO's concept of institutionalized nuclear burden-sharing among the allies.

If President Trump's declared radicalism on nuclear issues is translated into policy, it might even have the effect of strengthening alliances. Less concerned than his predecessor about Chinese (or U.S. domestic) reactions, Trump may be more willing to redeploy U.S. tactical nuclear weapons to the Republic of Korea when Pyongyang deploys an operational ICBM. This could have a favourable outcome with respect to blunting mounting proliferation pressures in Seoul with a major U.S. extended deterrence gesture (Fifield, 2016).

While the likely unpredictability of a Trump administration will test institutional arrangements with allies, we would maintain that alliances have confronted-and weathered-great challenges already. The Cold War and the post-Cold War transition severely tested the strength of U.S. alliances over time (think of U.S.-ROK tensions during the 1970s, or the 2003 split in NATO over Iraq), but the resilience of these institutions in the face of adversity has remained a persistent feature of international relations.

What might explain the "stickiness," as Knopf (2017) puts it, of existing alliance institutions? Knopf makes the good point that causality of alliance cohesion and alliance institutionalization runs both ways. We concur, and think that this may be a good explanation for the enduring nature of the differences between U.S. alliances in Asia and in Europe. If cohesion and institutionalization reinforce each other, the extent to which allies 
integrate may well become path-dependent. Here, we may then have an explanation for the enduring nature of the Cold War legacy that Lanoszka (2017) also highlights, and which explanations based on structural realism do not easily account for. The creation of formal dialogue on extended deterrence in the U.S.-ROK and U.S.-Japan alliances after the Cold War certainly signify closer relations, but they have also highlighted how special and peculiar the NATO arrangement of nuclear sharing and the Nuclear Planning Group remain. NATO continues on a path of integration of its own, which it entered when the United States (inadvertently) enmeshed the ability of Europe to defend itself with its own nuclear policy when it decided to "share" warheads in the 1950s (Freedman, 2003, chapters 20 and 21).

\section{Alliance institutions and national decision-making}

Even if alliances endure, however, how much do they really affect national decision-making? Jackson (2017) asks whether alliance institutions can "affect" a presidential decision even "when the U.S. president has no direct engagement with the institutional mechanisms of the alliance?" We would contend that they can and would: The realization that nuclear use would always require a deliberate and discrete decision by the US president led NATO to adopt the Athens guidelines in 1962. Alliances cannot bind the U.S. president's hand, but through institutionalized cooperation, allies can structure the types of choices available, and hence shape, though never determine, future decisions.

Knopf (2017) wonders about the "the larger implications" of our argument, in particular what he sees as our tendency "to imply an either/or choice." For Knopf, "Institutional arrangements about nuclear weapons are simultaneously about making U.S. assurances credible and about promoting alliance cohesion while giving allies voice opportunities regarding the outlines of U.S. strategy." With respect to nuclear cooperation, we concur with the assessment that allies seek to achieve many goals simultaneously, including extended deterrence, in addition to overall alliance cohesion. The main point we sought to underscore in our analysis is that, in the literature on the nuclear umbrella, the fixation on extended deterrence has effectively eclipsed more nuanced investigation of institutional factors that contribute to allied confidence and/or doubts, and the broader benefits for the alliance beyond assurance and deterrence. Indeed, Knopf's own work in this area has helped to open up many of these paths for investigation.

Lanoszka (2017) also observes that we "seem torn" on whether "the institutionalization of nuclear-armed alliances affect state behaviour." He points to our identification of relative bargaining power within alliances as being somewhat at odds with our emphasis on institutionalism in shaping behaviour. In our analysis, we cite examples where "junior" U.S. allies have achieved outcomes from intra-alliance bargaining that belie their material power status. Mearsheimer's argument (referred to by Lanoszka) that institutions have negligible independent effect on state behaviour is not borne out by the empirical record of U.S. alliances. Crude power asymmetries overlook the enabling role performed by institutions where those states with more at stake on specific issues drive harder in bargaining with the expectation the US will concede in order to preserve alliance unity. At the same time, the multilateral nature of NATO gives those states that sit in the middle on many issueshistorically a position often taken by the Benelux countries - much greater influence than they otherwise might have had. 
We do not deny the reality that material power shapes intra-alliance bargaining, but we do argue that is invariably moderated by institutional factors. And, in this context, the detail of nuclear force structure and alliance strategy do matter, insofar as alliance integration can make "power" depend on collective action. The Kennedy administration was certainly right that European NATO members by the 1960 s could field far more powerful military forces than in NATO's first decade, and it seemed to have leverage in that it was US nuclear warheads that were "shared" with its allies. But despite attempts by McNamara to make such supply conditional on European concessions on the raising of the nuclear threshold, the basic problem for the United States was that the force structure underpinning NATO's increased power had "baked into it" the assumption of early nuclear use. The United States needed a militarily stronger Europe to achieve the aims of "flexible response," but that strength depended on allied consensus on nuclear strategy (Tuschhoff, 2002).

\section{Allies and alliances under Trump}

The realization that alliances are probably less brittle, and perhaps more moderating of individual presidents' behaviour than suggested by Trump's disparaging tone during the presidential race, leads to the question of what role alliances and allies might play in U.S. global engagement beyond 20 January 2017. Jackson (2017) sees promise in our argument for the way the United States could implement the "third offset" strategy in an alliance framework. But although nuclear weapons are often described as the "first offset", we think that they remain singular in their political and strategic importance. If allied cooperation in the "third offset" is to move beyond research and technical cooperation to military integration and the creation of new, mutual dependence between allies in how to fight a great power war, such agreement is more likely to follow agreement on how to manage conflict at the nuclear level than the other way around.

Therefore, we think Jackson's (2017) suggestion of a "reverse NPG" after January 2017where allies make it their mission to influence U.S. thinking on nuclear policy- may be apposite and potentially highly relevant. This suggestion is premised on senior Trump administration officials emulating Kennedy and Johnson administration officials, who did adopt their thinking on the feasibility of conventional deterrence in Europe, and actually listened to what allies had to say. France and the United Kingdom have a particular opportunity (and perhaps responsibility) as the United States' only nuclear-armed allies to influence the new administration's thinking on nuclear policy (Lewis and Tertrais, 2015). The reinvigoration of NATO's deterrence messaging in the 2016 Warsaw Summit communiqué had at its heart agreement among NATO's three nuclear powers, whose leaders can relate to each other on nuclear matters like no other allies. Everything points to Trump having a far more personal way of transacting business than his somewhat detached predecessorbut the influence and importance of personalities in managing nuclear issues in the alliance is hardly a new phenomenon (Spohr, 2015).

This does, however, raise the interesting point that it might be easier to convince Trump that the United States needs allies (in particular, those who pull their weight), as distinct from alliances per se. In the Asian context of bilateral treaties, this is a distinction without difference. Yet, this is not so in Europe where France's intervention in Mali, or NATO 
members' contributions to the anti-ISIS coalition, formally bypass the alliance institutions we discuss in our article-although in all these conflicts as previously in Afghanistan and Iraq, NATO involvement tends to increase over time as it proves to be a more efficient, politically and organizationally, way of organizing allied contributions. In his response to our article, Knopf (2017) raises the point that Trump will need allies if he is to achieve his aim of tearing up-or significantly strengthening-the Iran nuclear agreement. One conclusion we draw from our own research is that Europeans should be open to debate such issues in the North Atlantic Council, as unpalatable as some of Trump's wishes might seem: Institutions can only bind and be effective if they are used. For all the concerns that US allies have about Trump and the damage he might cause, they cannot afford to cut off their nose to spite their face.

\section{Reference list}

Fifield, A. (2016). As North Korea flexes its muscles, some in South want nukes, too. Washington Post, 20 March. Retrieved from https://www.washingtonpost.com/world/asia_pacific/as-north-korea-flexes-its-musclesthe-other-korea-looks-at-nukes-too/2016/03/20/e2b1bb22-eb88-11e5-a9ce681055 c7a05f_story.html?utm_term=.3c83ca5099b5

Freedman, L. (2003). The evolution of nuclear strategy. $3^{\text {rd }}$ edition, Houndmills: Palgrave Macmillan.

Frühling, S. and O'Neil, A. (2017). Nuclear weapons, the United States and alliances in Europe and Asia: Toward and Institutional perspective. Contemporary Security Policy, 38, doi: 10.1080/13523260.2016.1257214

Jackson, V. (2016). Rival reputations: Coercion and credibility in US-North Korea relations. Cambridge: Cambridge University Press.

Jackson, V. (2017). Let's make a (nuclear) deal: bargaining, credibility, and the third offset strategy. Contemporary Security Policy, 38, doi: 10.1080/13523260.2016.1271967

Knopf, J. (2012). Varieties of assurance. The Journal of Strategic Studies, 35, 375-99. doi: 10.1080/01402390.2011.643567

Knopf, J. (2017). Security assurances and proliferation risks in the Trump administration. Contemporary Security Policy, 38, doi:10.1080/13523260.2016.1271688

Lanoszka, A. (2016). Russian hybrid warfare and extended deterrence in eastern Europe. International Affairs, 92, 175-195. doi: 10.1111/1468-2346.12509

Lanoszka, A. (2017). Goodbye to all that? Institutionalist theory, U.S. alliances, and Trump. Contemporary Security Policy, 38, doi:10.1080/13523260.2016.1268031

Lee, C. and Sonne, P. 2016. Trump Splits from U.S. Nuclear Policy. Wall Street Journal. 30 March. Retrieved from http://www.wsj.com/articles/trump-splits-from-u-s-nuclear-policy$\underline{1459383313}$ 
Lewis, J., and Tertrais, B. (2015). Deterrence at three: US, UK and French nuclear cooperation. Survival, 57, 29-52. doi: 10.1080/00396338.2015.1068554

Miller, F. and Payne, K. (2016). Trump's nuclear deterrence challenge. Wall Street Journal, 20 November. Retrieved from http://www.wsj.com/articles/trumps-nuclear-deterrencechallenge-1479680000

Sanger, D., and Haberman, M. (2016). In Donald Trump's worldview, America comes first, and everybody else pays. New York Times, 26 March. Retrieved from http://www.nytimes.com/2016/03/27/us/politics/donald-trump-foreign-policy.html?_r=0

Spohr, K. (2015). Helmut Schmidt and the shaping of Western security in the late 1970s: The Guadeloupe summit of 1979. International History Review, 37, 167-192. doi: http://dx.doi.org/10.1080/07075332.2013.836125

Tuschhoff, C. (2002). Deutschland, Kernwaffen und die NATO, 1949-1967. Baden: Nomos Verlagsgesellschaft.

Wayne, A. (2016). Trump says nuclear arsenal must be "greatly expanded". Bloomberg, 23 December. Retrieved from https://www.bloomberg.com/politics/articles/2016-12- 